\title{
Student Service Performance Analysis by Using Path Analysis Model
}

\author{
Nia Kurniati ,Farniwati Fattah, Mardiyyah Hasnawi
}

\begin{abstract}
Academic services are probably the most important aspect to achieve excellence in a university. Every university applies strategies to improve their service quality for example an integrated academic information system that has been run by Universitas Muslim Indonesia (UMI). Due to the students as the object of services, it is important to evaluate their level of satisfaction regarding to the academic service performance that they have experienced. This research aimed to analyze the students' satisfaction on a WEB based academic information system in UMI using path analysis. The research phases started from determining hypothesis, collecting questionnaire data, identifying variables, analyzing data using path analysis, and analyzing model. The variables tested were students' registration, course schedule, course grades and assistantships. In this research, a model was created to measure the level of users' satisfaction by information system based services. The results of this research is the level of satisfaction in student registration services that higher than the course schedule, course grades, and academic assistantships and a gain of confidence to the student that is equal to 17\%. Academic information system (SIMAK) on academic service system of UMI can be analyzed by using path analysis and obtained student satisfaction result $69 \%$.
\end{abstract}

Keywords: Academic Information System; Path Analysis; Service Quality.

\section{INTRODUCTION}

Web-based academic information system is an academic service that allows students to obtain the information needed via web. Universitas Muslim Indonesia (UMI) is one of universities that has implemented this system for three years. The information system was developed to assist students in obtaining academic information such as lecture schedules, students' registration, course grades, assignments, academic assistances.

The university services can be measured based on factors that affect the service quality. In this regard, path analysis can be employed. Path analysis is Structural Equation Modeling (SEM), the model formed describes the causal relationship between measured variables in the form of multiple linear regression [1]. Measurements can be made based on the consumer's assessment of the performance of a service [2], [3]. There are seven dimensions of service quality of academic namely, administrative services, tangibles, academic programs, academic staff, teaching delivery, certainty, and empathy [4].

Revised Version Manuscript Received on 10 September, 2019.

Nia Kurniati , Faculty of Computer Science, Universitas Muslim Indonesia, Makassar, Indonesia.(Email: nia.kurniati@umi.ac.id)

Farniwati Fattah, Faculty of Computer Science, Universitas Muslim Indonesia, Makassar, Indonesia.

Mardiyyah Hasnawi, Faculty of Computer Science, Universitas Muslim Indonesia, Makassar, Indonesia.
Consumer satisfaction is assessed from the level of service quality. Service satisfaction is a key to creating consumer loyalty. In the academic field, attention to the quality of academic services is necessary to achieve student satisfaction. Academic satisfaction is a multidimensional satisfaction. To know academic satisfaction can be done by evaluating education and knowing satisfaction from education environment [5]. Measurement of student satisfaction level is done by distributing questionnaires to factors that affect the quality of academic service. The respondent data is processed using statistical methods and the result is used to determine the causal relationship between service quality and other external factors of path analysis method. Some researchers have applied path analysis methods [6], [7]. Four models in path analysis i.e., students self-confidence, lecturer impact, perceptual assessment, and variables affecting service quality 2 . Path analysis to examine the relationship between classroom assessment, environmental assessment, and academic achievement [8]. In order to improve the service of an academic. This study was conducted to determine the level of user satisfaction and academic services by evaluating the quality of web-based academic information system at Universitas Muslim Indonesia (UMI)..

\section{EXPERIMENTAL DETAILS}

Problem solving in this study is to make a model in analysis a problem with service system that has been run. The factors were available in the service then generated the hypothesis that became a reference. This research was done in stages, among others, namely, 1. Determining the hypothesis, 2. Collecting data, 3. Identificating variables, 4. Testing using path analysis, and 5. Analysing a model.

\subsection{Formulate the hypothesis}

The statistical hypothesis is formulated as follows:

Ha $: \mathrm{PyX} 1=\mathrm{PyX} 2=\mathrm{PyX} 3=\mathrm{PyX} 4 \neq 0$ (Not significant) Ho $:$ PyX1 = PyX2 = PyX3 = PyX4 = 0 (Significant)

Example of hypothesis for variable (X1):

Ha: The influence of student registration services on the academic service system has a positive on effect achieving student satisfaction.

Ho: The influence of student registration services on the academic service system has a negative on effect achieving student satisfaction. 


\subsection{Phase of data collection}

The data comes from the student population data that is active in the Faculty of Computer Science UMI. There were 107 respondents in the distribution of questionnaires [9]. Measurement of the questionnaire using likert scale.

\subsection{Identify variables}

Implementation of path analysis can be done to determine the influence directly or indirectly. The effect directly had no intermediate variable while indirectly can consist of one or more additional variables [10]. Path analysis was a method used to analyze the relationship patterns of variables and the aim to determine the direct influence of independent variables (exogenous) to the dependent variable (endogenous). Independent variable (exogen) was student registration $\left(X_{1}\right)$, college schedule $\left(X_{2}\right)$, course grade $\left(X_{3}\right)$, and ac assistantships $\left(X_{4}\right)$ while dependent variables (endogen) to student satisfaction $(Y)$.

\subsection{Line coefficient calculation}

Path coefficient was calculated by multiplying the inverse matrix of independent variable correlation between dependent variables by SPSS 24 application. Anova tests result obtained value of $\mathrm{F}$ equal to 11.603 with probability value $($ Sig. $)=0.000$. Because of the value of sig $<0.01$, it can be said the quality of service simultaneously affected the consumer satisfaction. Therefore, individuals testing can be performed. The value of $\mathrm{F}$ is calculated by the formula that is $\mathrm{F}=K\left(1-R^{2} y \cdot X_{1}, X_{2}, X_{3}, X_{4}, X_{n}\right)$. The value of $R^{2} y X_{1}, X_{2}, X_{3}, X_{4}$ is 0.313 ( $R$ Square), for $P y_{\mathcal{C}}$ is obtained from $P y_{\bar{C}}=$ $1-R^{2} y \cdot X_{1}, X_{2}, X_{3}, X_{4}$. The formula for obtaining relationships between $X_{1}, X_{2}, X_{3}, X_{4}$ to $Y$ can be calculated by equations $Y=$ $P y x 1 X_{1}+P y x 2 X_{2}+P y x 3 X_{3}+P y x 3 X_{4}+P y_{\mathcal{C}}$

\section{RESULT AND DISCUSSION}

In this research, a model is created to measure the level of user satisfaction by information system based services. Figure 1 shows the Model Analysis of Research Problems. Testing the validity of this study attention to the number on Corrected Item-Total Correlation which is the correlation between the item scores with the total item score. On computational calculation process yields correlation values on each variable. Table 1 shows the correlation results $\mathrm{X} 1$, $\mathrm{X} 2, \mathrm{X} 3$, and $\mathrm{X} 4$ to student satisfaction (Y).



Fig. 1: Model analysis of research problem
Table 1: Correlation Results X1, X2, X3, and X4 on Student Satisfaction (Y)

\begin{tabular}{|c|c|c|c|c|c|}
\hline Model & $\begin{array}{c}\text { Student } \\
\text { Registra- } \\
\text { tion } \\
\text { (X1) }\end{array}$ & $\begin{array}{l}\text { Course } \\
\text { Sched- } \\
\text { ule } \\
\text { (X2) }\end{array}$ & $\begin{array}{l}\text { Cours } \\
\text { e } \\
\text { Grad } \\
\text { es } \\
\text { (X3) }\end{array}$ & $\begin{array}{l}\text { Assis- } \\
\text { tantships } \\
\text { (X4) }\end{array}$ & $\begin{array}{c}\text { Satisfac- } \\
\text { tion } \\
\text { (Y) }\end{array}$ \\
\hline $\begin{array}{l}\text { Student } \\
\text { Registra- } \\
\text { tion (X1) }\end{array}$ & 1.000 & -0.014 & 0.381 & 0.142 & 0.457 \\
\hline $\begin{array}{l}\text { Course } \\
\text { Schedule } \\
\text { (X2) }\end{array}$ & -0.014 & 1.000 & 0.061 & 0.175 & -0.021 \\
\hline $\begin{array}{c}\text { Course } \\
\text { Grades } \\
\text { (X3) }\end{array}$ & 0.381 & 0.061 & 1.000 & 0.355 & 0.447 \\
\hline $\begin{array}{c}\text { Assis- } \\
\operatorname{tantships} \\
\text { (X4) }\end{array}$ & 0.142 & 0.175 & 0.355 & 1.000 & 0.269 \\
\hline $\begin{array}{l}\text { Satisfaction } \\
\text { (Y) }\end{array}$ & 0.457 & -0.021 & 0.447 & 0.269 & 1.000 \\
\hline
\end{tabular}

Based on Table. 1 it shows that the correlation between variable student registrations (X1) to customer satisfaction (Y) has an effect of 0.457 which meant that the relationship between the two variables was stronger rather than the other variables. Whereas, the variable of course grades (X2) to customer satisfaction (Y) has an effect of -0.021 which that the relationship between the two variables was not strong compared with other variables. The regression coefficient resulting each variable was tested. The following test results regression coefficient statistics in Table. 2.

Table 2: Test Results of Regression Coefficient Statistics

\begin{tabular}{|c|c|c|c|c|c|}
\hline Model & $\begin{array}{c}\text { Unstandard- } \\
\text { ized } \\
B\end{array}$ & $\begin{array}{l}\text { Coeffi- } \\
\text { cient Std. } \\
\text { Error } \\
\text { Std. }\end{array}$ & $\begin{array}{l}\text { Standard- } \\
\text { ized Coef- } \\
\text { ficient } \\
\text { Beta }\end{array}$ & $\mathrm{t}$ & Sig. \\
\hline (Constant) & 2.830 & 10.308 & & $\begin{array}{c}0.27 \\
4\end{array}$ & $\begin{array}{c}0.78 \\
4\end{array}$ \\
\hline $\begin{array}{c}\text { Student } \\
\text { Registration } \\
\text { (X1) }\end{array}$ & 0.421 & 0.113 & 0.332 & $\begin{array}{c}3.73 \\
9\end{array}$ & $\begin{array}{c}0.00 \\
0\end{array}$ \\
\hline $\begin{array}{l}\text { Course } \\
\text { Schedule } \\
\text { (X2) }\end{array}$ & -0.089 & 0.131 & -0.057 & $\begin{array}{c}- \\
0.67 \\
9\end{array}$ & $\begin{array}{c}0.83 \\
2\end{array}$ \\
\hline $\begin{array}{l}\text { Course } \\
\text { Grades } \\
\text { (X3) }\end{array}$ & 0.367 & 0.125 & 0.277 & $\begin{array}{c}2.94 \\
3\end{array}$ & $\begin{array}{c}0.00 \\
0\end{array}$ \\
\hline $\begin{array}{l}\text { Assis- } \\
\text { tantships } \\
(\mathrm{X} 4)\end{array}$ & 0.175 & 0.117 & 0.134 & $\begin{array}{c}1.50 \\
4\end{array}$ & $\begin{array}{c}0.00 \\
5\end{array}$ \\
\hline
\end{tabular}

The test results shown in Table 2. that the values of sig. on the variables $X_{1}, X_{3}$, and $X_{4}$ smaller than 0.01 therefore it was stated significant to the variable $Y$ then, $\left(\mathrm{H}_{\mathrm{o}}\right.$ is rejected $)$ in the sense of student registration services, course grades and assistantships got positive response to student satisfaction, while variable $X_{2}$ greater than 0.01 , so declared not significant to variable $Y$ then, $\left(\mathrm{H}_{\mathrm{o}}\right.$ accepted $)$ means of service schedule of course did not get positive response to student satisfaction. The path coefficient was calculated by inverse the inverse matrix of the correlation between the independent variable (exogen) with the dependent variable (endogenous). The results of computational test obtained direct influence value, Total influence together. The joint effect of $\left(R^{2} y \cdot X_{1}, X_{2}, X_{3}, X_{4}\right)$ was derived from a predefined formula.

Based on calculation of path analysis, obtained $R$ Square equal to 0,313 . The results of regression test shows that all

Published By: Blue Eyes Intelligence Engineering 
the independent variables are student registration $\left(X_{1}\right)$, course schedule $\left(X_{2}\right)$, course grades $\left(X_{3}\right)$, and assistantships $\left(X_{4}\right)$ can explain as much as $69 \%$ have relationship to dependent variable that is on student satisfaction $(Y)$. and for other variables explained by $31 \%$. The Following is result of objective information based on the calculated path coefficients:

a. The strength of the variable $X_{1}$ on directly determines the change of the variable $Y$ is $11,0 \%(0.110)$. Thus total of $X_{l}$ to $Y$ is $17.7 \%$.

b. The strength of the variable $X_{2}$ on directly determines the change of the variable $Y$ is $0.32 \%$ (0.0032). Thus total of $X_{2}$ to $Y$ is $0.22 \%$

c. The strength of the variable $X_{3}$ on directly determines the change of the variable $Y$ is $7.6 \%(0.076)$. Thus total of $X_{3}$ to $Y$ is $9.39 \%$.

d. The strength of the variable $X_{4}$ on directly determines the change of the variable $Y$ is $1.79 \%(0.0179)$. Thus total of $X_{4}$ to $Y$ is $3.99 \%$.

\section{CONCLUSION}

In this research, a model is created to measure the level of user satisfaction by information system based services. The level of satisfaction in student registration services that higher than the course schedule, course grades, and assistantships and a gain of confidence to the student that is equal to $17 \%$. Regression tests results obtained $\mathrm{R}$ Square it is 0.313. The variables $\mathrm{X} 1, \mathrm{X} 3$, and $\mathrm{X} 4$ have a significant influence on the variable $\mathrm{Y}$ in terms of registration service, course grades and assistantships of students get positive responses to student satisfaction, whereas for the variable X2 are not significant to the $\mathrm{Y}$ variable which means the service of course schedules does not get positive response to student satisfaction. Academic information system (SIMAK) on academic service system of UMI can be analysed by using path analysis and obtained student satisfaction result $69 \%$.

\section{REFERENCES}

1. A. Pruttiakaravanich and J. Songsiri, "A convex formulation for path analysis in structural equation modeling," in 2016 55th Annual Conference of the Society of Instrument and Control Engineers of Japan, 2016, pp. 282-287.

2. A. Sellami, R. C. El-Kassem, H. B. Al-Qassass, and N. A. Al-Rakeb, "A Path Analysis of Student Interest in STEM, with Specific Reference to Qatari Students," EURASIA J. Math. Sci. Technol. Educ., vol. 13, no. 9, pp. 6045-6067, 2017.

3. A. Pruttiakaravanich and J. Songsiri, "A convex formulation for path analysis in structural equation modeling," in 2016 55th Annual Conference of the Society of Instrument and Control Engineers of Japan, 2016, pp. 282-287.

4. A. Sellami, R. C. El-Kassem, H. B. Al-Qassass, and N. A. Al-Rakeb, "A Path Analysis of Student Interest in STEM, with Specific Reference to Qatari Students," EURASIA J. Math. Sci. Technol. Educ., vol. 13, no. 9, pp. 6045-6067, 2017.

5. E. Budiman, N. Dengan, A. H. Kridalaksana, and M. Wati, "Performance of Decision Tree C4. 5 Algorithm in Student Academic Evaluation," in International Conference on Computational Science and Technology, 2017, pp. 380-389.

6. S. Ahmed and M. M. Masud, "Measuring Service Quality of a Higher Educational Institute towards Student Satisfaction," Am. J. Educ. Res., vol. 2, no. 7, pp. 447-455, 2012.

7. M. Shirazi, "Student satisfaction analysis and its factors (2014 to 2016)," Education, vol. 7, no. 4, pp. 71-81, 2017.

8. Tahyudin, R. Rosyidi, A. S. Ahmar, and Haviluddin, "C omparison of the Simple Additive Weighting (SAW) with the Technique for Others Reference by Similarity to Ideal Solution (TOPSIS) methods," Int. J. Eng. Technol., vol. 7 , no. 2, pp. 87-98, 2018

9. E. Budiman, N. Dengen, Haviluddin, and W. Indrawan, "Integrated multi criteria decision making for a destitute problem," in 2017 3rd International Conference on Science in Information Technology, 2017, pp. 342-347.

10. H. Alkharusi, "Classroom Assessment Communication, Perceived Assessment Environment, and Academic Achievement: A Path Analysis," Br. J. Educ. Soc. Behav. Sci., vol. 8, no. 2, pp. 117-126, 2015.

11. W. M. A. B. W. Afthanorhan and S. Ahmad, "Path analysis in covariance-based structural equation modeling with Amos 18.0," Eur. J. Bus. Soc. Sci., vol. 2, no. 10, 2014.

12. R. Lynch and M. H. Dembo, "International review of research in open and distance learning," Rev. Educ. Res. Open Distance Learn., vol. 5, no. 2, pp. 33-45, 2004 